\title{
Short communication: Trends for monthly changes in days open in Holsteins
}

\author{
M. Pszczola, ${ }^{*} \dagger^{1}$ I. Aguilar, ${ }^{*} \ddagger$ and I. Misztal ${ }^{*}$ \\ ${ }^{*}$ Animal and Dairy Science Department, University of Georgia, Athens 30602 \\ †Animal Breeding and Genetics Group, Wageningen Institute of Animal Sciences, Wageningen University, $6700 \mathrm{AH}$ Wageningen, the Netherlands \\ ‡Instituto Nacional de Investigación Agropecuaria, Las Brujas, Uruguay
}

\section{ABSTRACT}

A reaction norm approach was used to estimate trends for days open (DO) with a model that indirectly accounted for heat stress. Data included 3.4 million first-parity records of DO of US Holsteins. A fixed effect model included herd-year, month of calving within region (MOC), age class, and regression on 305-d milk yield. An index calculated from the standardized solutions to MOC derived from the fixed effect model was treated as a proxy for an index on heat stress (SI). The lowest index for any region was set to zero. The highest index was 1.00 for the Southeast, 0.56 for the Northeast, 0.54 for the Midwest, 0.33 for the Northwest, and 0.42 for the Southwest. In all regions except the Northwest, the highest DO and the corresponding highest indices were in March-April. Compared with the fixed model, the reaction norm model also included the effect of an animal and a random regression on the SI; the 2 animal solutions are subsequently referred to as an intercept and a slope. Genetic trends were calculated for cows and sires separately. For cows, the trend for the intercept was $-0.1 \mathrm{~d} / \mathrm{yr}$, whereas the trend for the slope was $1 \mathrm{~d} / \mathrm{yr}$. For sires, the same trends were -0.3 and 1.5 , respectively. Official proofs were used to characterize the 100 top and 100 bottom bulls with at least 50 daughters for the intercept and the slope. Compared with the top bulls, the bottom bulls for the intercept gave $56 \mathrm{~kg}$ more milk and their type performance index was higher by 212 points. For the slope, the same numbers were $-435 \mathrm{~kg}$ and -242 points, respectively. Trends for seasonal changes of days open are unfavorable.

Key words: dairy cattle, fertility, days open, heat stress

Decline in fertility traits in many dairy cattle breeds is well documented (Washburn et al., 2002; RajalaSchultz and Frazer, 2003; de Vries and Risco, 2005) and has a negative effect on the income of dairy farmers (de Vries, 2006). As those traits are lowly heritable, they

Received December 17, 2008.

Accepted May 5, 2009.

${ }^{1}$ Corresponding author: mbee@jay.au.poznan.pl are difficult to improve by genetic selection. These traits have unfavorable correlations with production (Berger et al., 1981; Abdallah and McDaniel, 2000; Pryce et al., 2004). Therefore, increased selection for production while ignoring fertility results in reduced fertility.

A large fraction of the variability of fertility traits is determined by environmental factors such as herd effect or season of calving (Faust et al., 1988; Ray et al., 1992; Eicker et al., 1996). The variability of days open (DO) in the month of calving has been shown by several investigators (Silva et al., 1992; VanRaden et al., 2002; Oseni et al., 2003). According to their results in the United States, DO were longest for spring and shortest for fall calvings. Seasonal trends for DO and for most of the fertility traits were partly attributed to the variation in temperature. High temperature combined with a high level of humidity results in physiological disorders, affecting the digestive system, acid-base chemistry, and blood hormones (Rensis and Scaramuzzi, 2003; West, 2003).

Decreasing heat tolerance may be one of the reasons for decline in fertility. Aguilar et al. (2008) found positive genetic trends for daily milk yield in the first 3 parities when heat stress was absent. However, the rate of decline under heat stress increased, especially in the second and third parities. The sensitivity to heat stress increased with the subsequent number of parities from first to third (Aguilar et al., 2008). García-Ispierto et al. $(2006,2007)$ reported a similar negative influence of heat stress on fertility. Thus, observed seasonal patterns in fertility traits might be considered a result of the high temperatures in summer months and their negative influence on reproductive performance.

Most high-producing farms in areas where heat stress is present use cooling devices. Although the decline in milk yield over the summer can be greatly reduced under good heat management, the decline in fertility under heat stress is still strong (Her et al., 1988; Flamenbaum and Ezra, 2007). The effect of heat stress on fertility is currently observed not only in the southern US but also as far north as Alberta, Canada (Brouk et al., 2007). One way to counteract this decline is through genetic selection. 
Arguably, the preferable way for genetic evaluation of fertility under heat stress would be the analysis of the nonreturn rate while accounting for temperature conditions at the time of the first insemination (Ravagnolo and Misztal, 2002) or the extension of this technology for outcomes of all inseminations (Averill et al., 2004; Gonzalez-Recio et al., 2005). However, the availability of insemination data in the United States is limited (Huang et al., 2008). An alternative solution is to consider DO that is available from the AIPL/ USDA database and is used for US genetic evaluation. Oseni et al. (2004a) estimated the genetic parameters for DO under varying levels of heat stress using a reaction norm model for the southeastern United States. On the one hand, the increase of DO under heat stress was already apparent, and no weather data were necessary for the analysis. On the other hand, changes in DO seemed to be influenced also by management factors and only indirectly related to heat stress. The reaction norm involves an index derived from solutions for the month of calving (MOC) effect; rescaling resulted in an index from zero (MOC with lowest DO) to 1 (MOC with highest DO; Oseni et al., 2004a).

The aim of this study was to extend the model of Oseni et al. (2004a) to all regions of the United States and to run the national genetic evaluation of DO with that model to obtain genetic trends.

Production and DO records on 3,401,130 first-parity Holsteins born from 1994 to 2000 in 32,203 herds were extracted from the AIPL/USDA database. The data set included records of 101,764 sires. Days open were precomputed as in VanRaden et al. (2003). Replicates, incorrect records, and DO with values $<22 \mathrm{~d}$ were removed from the data set. Range for DO was set from 50 to $250 \mathrm{~d}$; values between 22 and $50 \mathrm{~d}$ were set to $50 \mathrm{~d}$, and values exceeding $250 \mathrm{~d}$ were set to $250 \mathrm{~d}$.

The fixed model to estimate MOC solutions was

$$
y_{i j k l m}=h y_{i}+m_{o c} c_{k}+a g e_{l}+b \times m i l k+e_{i j k l m},
$$

where $y_{i j k l m}$ is observed DO for $m$ th $(m=1-3,401,130)$ animal in the herd-year class $i$ (hy; $i=1-34,862$ ), calving in month $j$ (moc; $j=1-12)$, in region $k(k=1-5)$, and in age-class $l$ (age; $l=1-6) ; b$ is a fixed regression on a 305-d milk yield (milk), and $e$ is the residual term. The standardized solutions for MOC were used to compute a monthly seasonal index (SI), using the following formula:

$$
S I_{j k}=\left(\operatorname{sol}_{j k}-s o l_{\min k}\right) / \alpha,
$$

where $s o l_{j k}$ is the least square solution for $j$ th MOC $(j=1-12)$ within $k$ th region $(k=1-5)$; $\operatorname{sol}_{\min k}$ is the minimum solution for the particular region, and $\alpha$ is a constant value that scales the index from 0 to 1 .

The genetic evaluation analysis used the following model:

$$
\begin{aligned}
y_{i j k l m}= & h y_{i}+\operatorname{moc}_{j k}+a g e_{l}+b \times \text { milk } \\
& +a_{0 m}+a_{1 m} S I_{j k}+e_{i j k l m},
\end{aligned}
$$

where $y_{i j k l m}, h y_{i}, m_{j} c_{j k}, a g e_{l}, b \times m i l k$, and $e$ are defined as in the first model; $a_{0 m}$ is the additive effect of animal $m$ at SI equals zero (intercept) $(m=1-3,401,130)$, and $a_{1 m}$ is the random regression coefficient for cow $m$ at a given SI (slope). Variance components were as in Oseni et al. (2004b); residuals among MOC were assumed to be heterogeneous. Additional analysis included a simplified model with the effect due to slope removed. Variance components for the simplified model were reestimated to consider the removal of SI. Estimates from the model were used to calculate genetic trends for the additive effects for cows and proven sires separately. Differences among estimates for group of cows and sires in both analyses were examined using the $t$-test.

Table 1 shows the distribution of records among the different states and regions; regions were defined as in Figure 1. The largest was the Midwest population, with nearly $1,193,707$ cows in 17,528 herds. The smallest number of animals (120,966 in 1,255 herds) was found in the Southeast. Over $50 \%$ of all observations were from the following 4 states: California, Wisconsin, New York, and Minnesota $(0.8,0.4,0.3$, and 0.3 million animals, respectively). The average DO was $135 \mathrm{~d}$. The Southeast had the highest mean of all the regions (154 d), whereas the Northwest the lowest mean (131 d).

Figure 2 shows phenotypic changes of DO across MOC with base adjusted so that the lowest estimate of MOC is zero; these changes are rescaled to an index in Figure 3. The highest values were in spring and summer and the lowest in fall and winter (Figure 2). This is similar to findings of Oseni et al. (2003), who attributed the changes to heat stress. Shapes of DO by month were somewhat different among regions. The shape for the Southeast was the most variable. The shape was somewhat different for the Northwest where the peak and the bottom were reached earlier than in the other regions; the Northwest was the region with the smallest magnitude of heat stress.

Figures 4 and 5 show the genetic trends for cows and sires, respectively. Trends were also plotted for the simplified model (with effect due to SI removed). Differences among estimates for cows and sires were highly significant for both models $(P<0.0001)$. When the index is not in the model, the trends for DO are flat. These findings differ from those presented by VanRaden 
Table 1. Distribution of records among the different states and regions

\begin{tabular}{|c|c|c|c|c|}
\hline \multirow[b]{2}{*}{ Region/state } & \multirow[b]{2}{*}{ Records, n } & \multirow[b]{2}{*}{ Herds, $\mathrm{n}$} & \multicolumn{2}{|c|}{ Days open } \\
\hline & & & Mean & SD \\
\hline \multicolumn{5}{|l|}{ Midwest } \\
\hline Iowa & 82,129 & 1,403 & 142 & 67 \\
\hline Illinois & 43,326 & 711 & 149 & 69 \\
\hline Indiana & 36,377 & 555 & 143 & 68 \\
\hline Kansas & 27,979 & 366 & 149 & 73 \\
\hline Kentucky & 15,098 & 295 & 149 & 71 \\
\hline Michigan & 114,444 & 1,179 & 136 & 66 \\
\hline Minnesota & 301,030 & 4,261 & 139 & 66 \\
\hline Missouri & 22,969 & 501 & 149 & 71 \\
\hline North Dakota & 6,167 & 90 & 143 & 68 \\
\hline Nebraska & 23,687 & 286 & 149 & 70 \\
\hline Ohio & 96,994 & 1,152 & 140 & 67 \\
\hline South Dakota & 16,935 & 269 & 144 & 69 \\
\hline Wisconsin & 399,633 & 6,385 & 128 & 64 \\
\hline Wyoming & 6,939 & 75 & 141 & 69 \\
\hline Midwest total & $1,193,707$ & 17,528 & 137 & 66 \\
\hline \multicolumn{5}{|l|}{ Northeast } \\
\hline Connecticut & 14,681 & 127 & 135 & 67 \\
\hline Delaware & 5,144 & 33 & 146 & 71 \\
\hline Massachusetts & 11,154 & 138 & 134 & 65 \\
\hline Maryland & 44,806 & 466 & 141 & 68 \\
\hline Maine & 13,727 & 178 & 134 & 64 \\
\hline New Hampshire & 12,001 & 121 & 135 & 65 \\
\hline New Jersey & 8,635 & 106 & 143 & 68 \\
\hline New York & 300,067 & 3,243 & 132 & 65 \\
\hline Pennsylvania & 298,101 & 5,161 & 135 & 65 \\
\hline Rhode Island & 283 & 6 & 145 & 66 \\
\hline Virginia & 68,400 & 610 & 140 & 67 \\
\hline Vermont & 45,034 & 545 & 132 & 64 \\
\hline Northeast total & 822,033 & 10,734 & 135 & 66 \\
\hline \multicolumn{5}{|l|}{ Northwest } \\
\hline Idaho & 71,095 & 232 & 134 & 66 \\
\hline Montana & 7,179 & 65 & 136 & 63 \\
\hline Oregon & 40,028 & 209 & 138 & 65 \\
\hline Washington & 83,640 & 286 & 136 & 65 \\
\hline Wyoming & 763 & 6 & 122 & 63 \\
\hline Northwest total & 202,705 & 798 & 135 & 65 \\
\hline \multicolumn{5}{|l|}{ Southeast } \\
\hline Alabama & 4,923 & 61 & 153 & 73 \\
\hline Arkansas & 3,252 & 74 & 156 & 71 \\
\hline Florida & 19,882 & 89 & 161 & 72 \\
\hline Georgia & 20,889 & 201 & 154 & 72 \\
\hline Louisiana & 7,506 & 120 & 154 & 73 \\
\hline Mississippi & 7,967 & 97 & 158 & 74 \\
\hline North Carolina & 27,087 & 252 & 151 & 71 \\
\hline South Carolina & 10,858 & 93 & 151 & 71 \\
\hline Tennessee & 18,602 & 268 & 152 & 72 \\
\hline Southeast total & 120,966 & 1,255 & 154 & 72 \\
\hline \multicolumn{5}{|l|}{ Southwest } \\
\hline Arizona & 48,764 & 53 & 132 & 64 \\
\hline California & 835,253 & 1,050 & 128 & 67 \\
\hline Colorado & 30,798 & 85 & 144 & 68 \\
\hline New Mexico & 27,275 & 42 & 129 & 65 \\
\hline Nevada & 8,195 & 21 & 132 & 66 \\
\hline Oklahoma & 8,135 & 135 & 156 & 72 \\
\hline Texas & 68,769 & 298 & 149 & 73 \\
\hline Utah & 34,530 & 204 & 145 & 67 \\
\hline Southwest total & $1,061,719$ & 1,888 & 131 & 67 \\
\hline All United States & $3,401,130$ & 32,203 & 135 & 67 \\
\hline
\end{tabular}




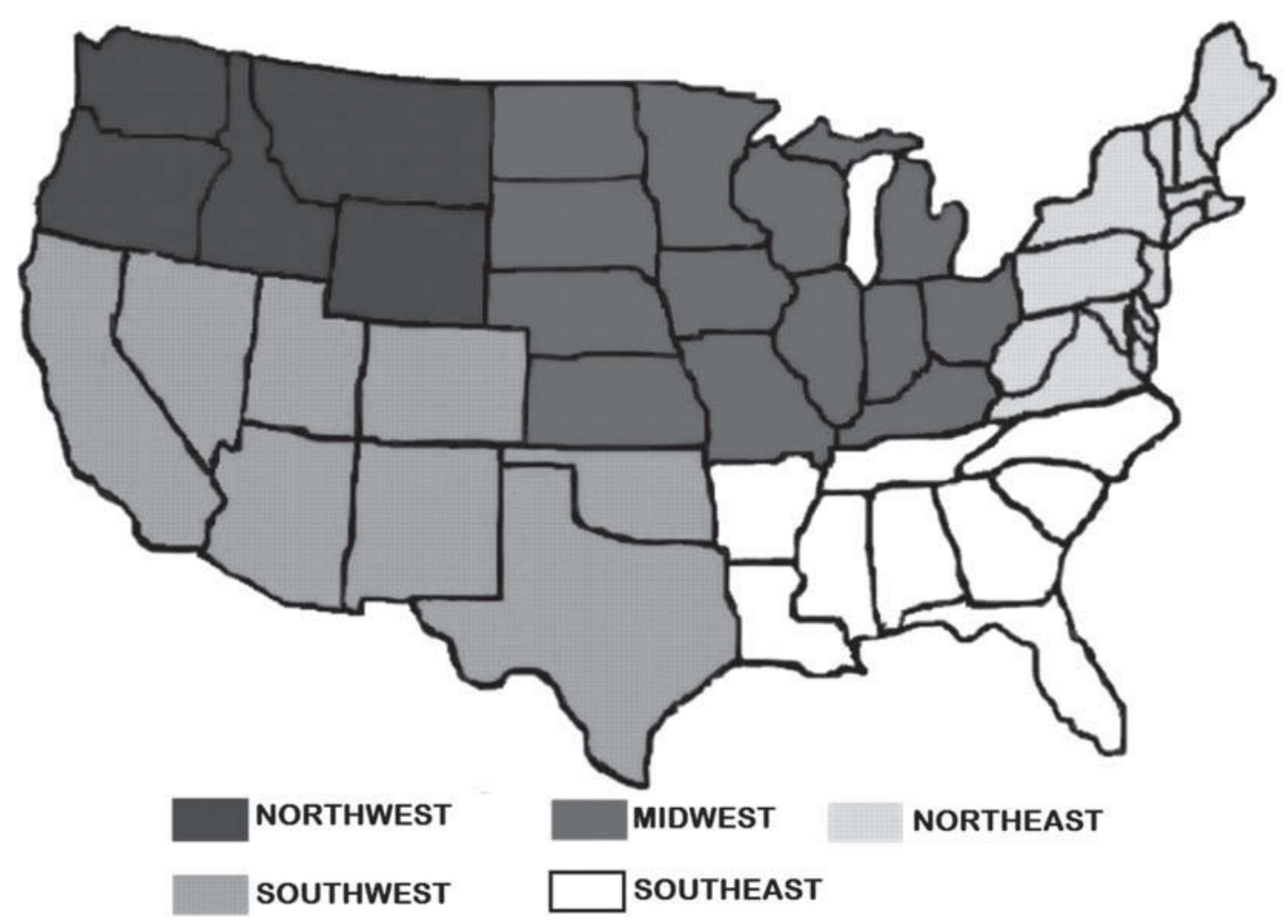

Figure 1. Map of the United States; distribution of states by region.

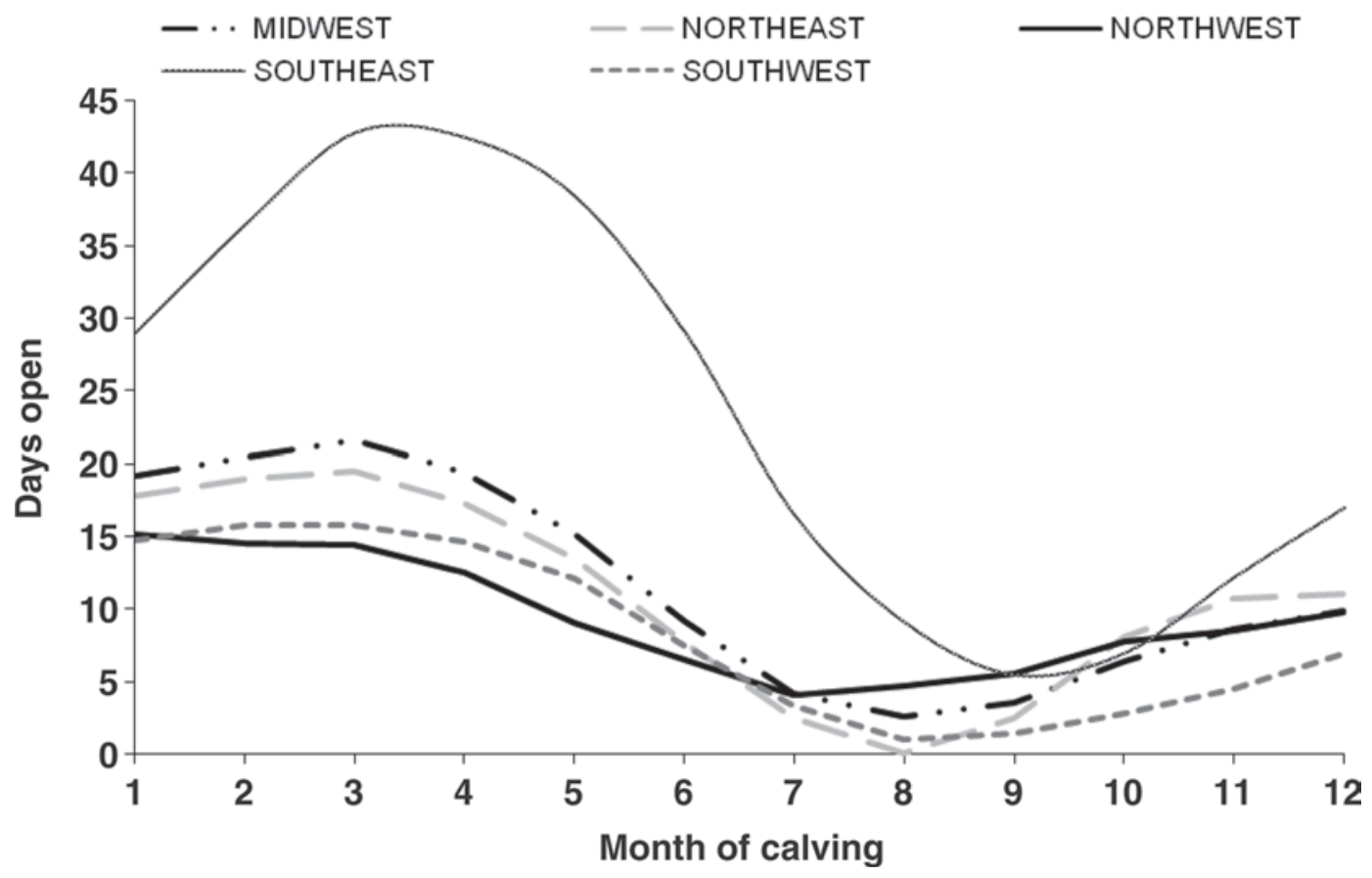

Figure 2. Phenotypic changes of days open across month of calving in different regions of the United States. 


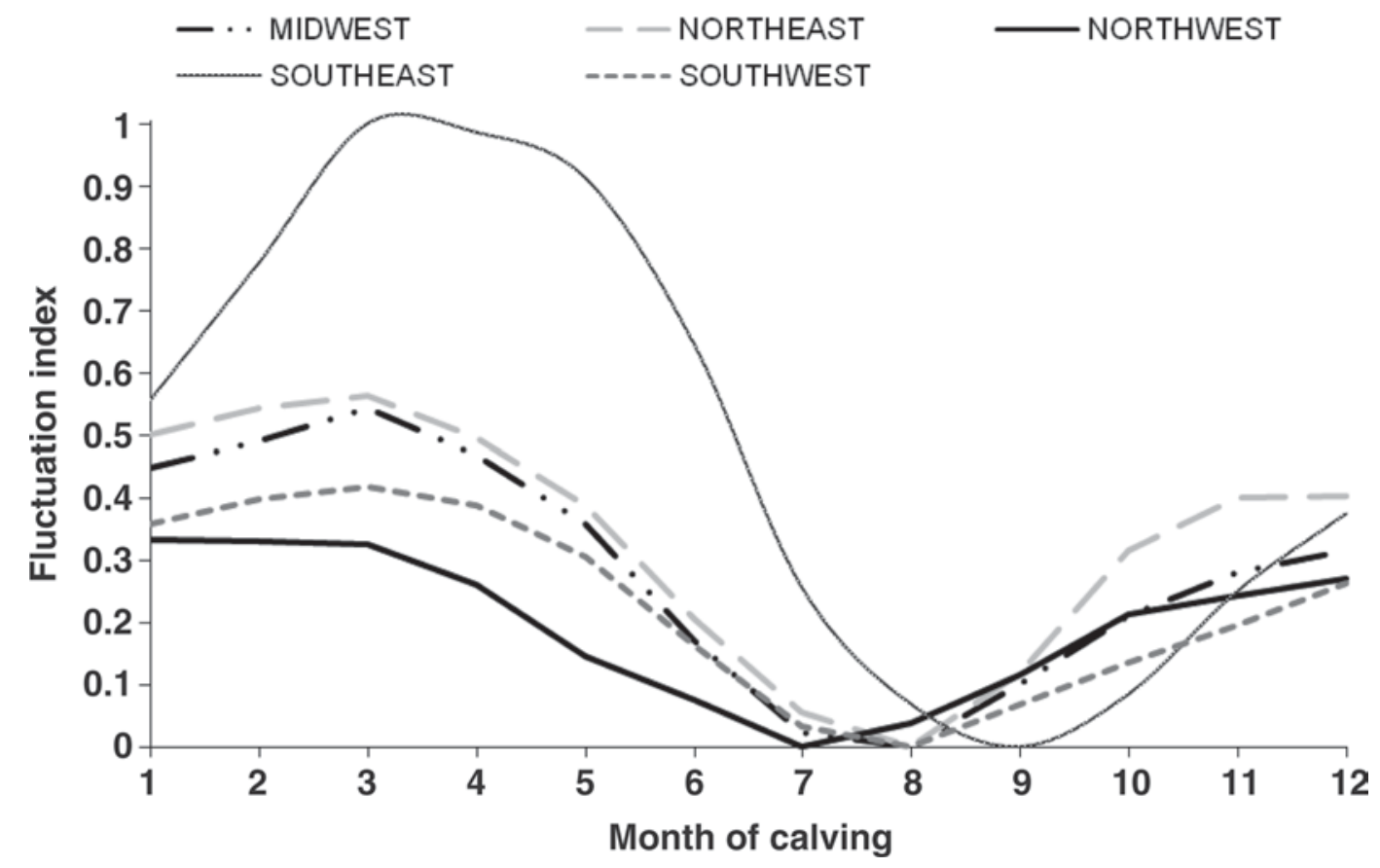

Figure 3. Index of changes of days open across month of calving in different regions of the United States.

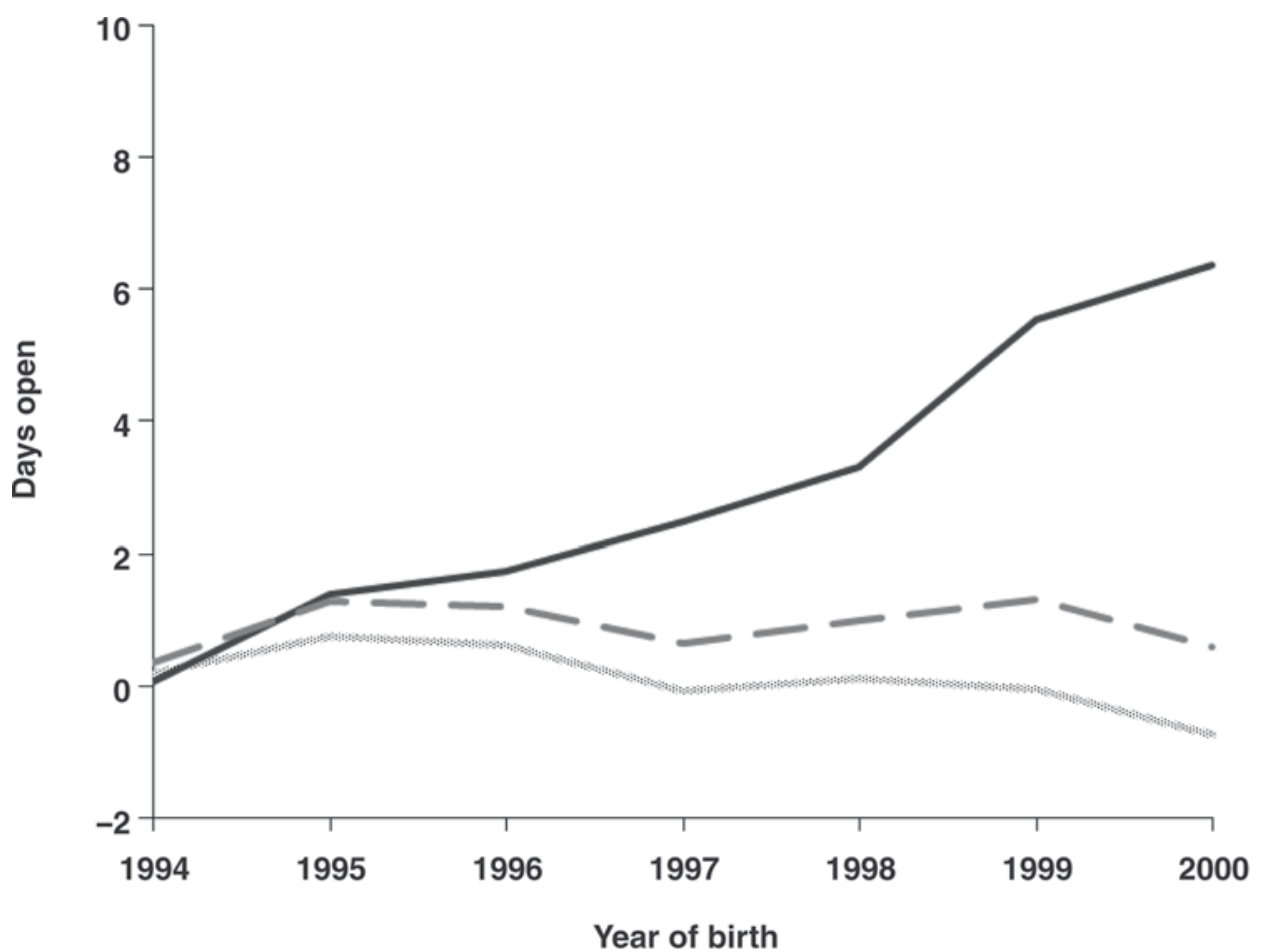

m intercept $\quad$ slope - -intercept in the simplified model

Figure 4. Genetic trends for cows for days open across past years; plotted for the full model with seasonal index (SI) included and simplified model with effect due to SI removed. 


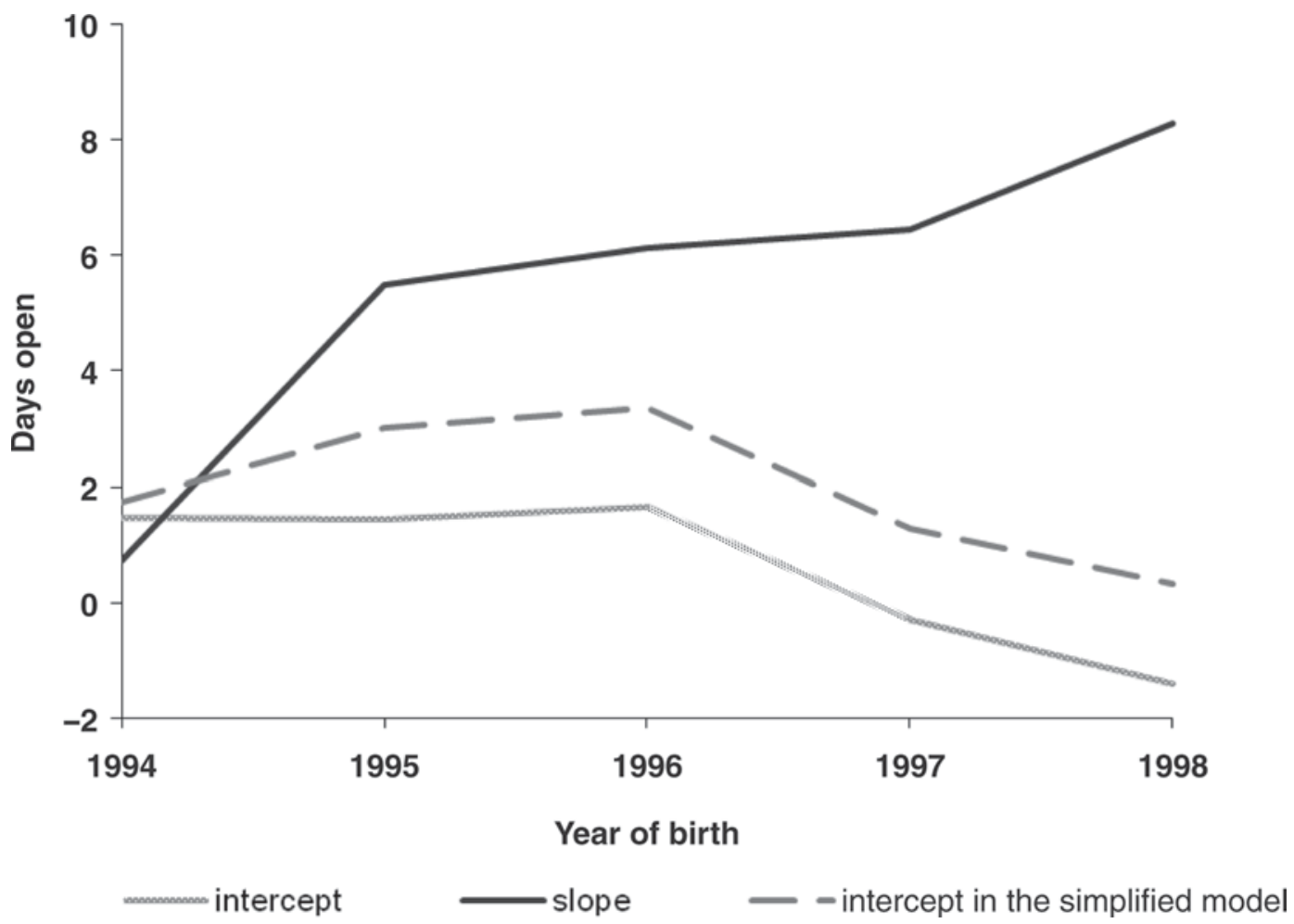

Figure 5. Genetic trends for sires for days open across past years; plotted for the full model with seasonal index (SI) included and simplified model with effect due to SI removed.

et al. (2004). However, in their model, there was no correction for milk yield and 5 parities were included. With the index in the model, the trend for the intercept (called the regular effect) is slightly negative at about $-0.1 \mathrm{~d} / \mathrm{yr}$, whereas the slope (called changes) is about $1 \mathrm{~d} / \mathrm{yr}$. The same trends for sires were -0.3 and $1.5 \mathrm{~d}$, respectively.

To create a profile of top and bottom bulls for selected traits, the top 100 and bottom 100 bulls with at least 50 daughters were selected separately for the intercept in the simplified and regular models, and for the changes. For those bulls, official US PTA for February 2005 were obtained (Table 2). Bulls with the smallest changes of DO transmitted much less milk yield (435 $\mathrm{kg}$ ) and a smaller type performance index (TPI; 242 points). It seems that bulls that transmit low changes would be undesirable based on their production and type. Contrary, bulls with the highest changes have, in general, superior characteristics, although their productive life $(\mathbf{P L})$ and daughter pregnancy rate (DPR) are below average. For the intercept with the full model, the bulls with the lowest DO gave $56 \mathrm{~kg}$ of milk and were superior for TPI by 212 points. They were also superior for DPR and PL. In the simplified model, the bulls with the lowest DO had daughters with slightly lower milk, superior TPI, and superior DPR and PL (but slightly lower than with the full model). See Table 2 for a detailed comparison.

Tsuruta et al. (2008) showed that cows kept on large farms had higher milk production and fewer DO. Fewer DO on large farms were due to more timed AI services compared with smaller farms. This is in agreement with the current results. When SI $=0$, bulls with fewer DO had higher values for milk yield; similarly, type trait scores were more desirable. Conversely, when SI was greater than zero, bulls with fewer DO had lower values of milk yield and type traits. Therefore, high-producing cows had greater changes of DO due to heat stress. When the conception rate is low, such as during heat stress, there is a tendency to use semen of less expensive bulls. This may explain the unexpectedly low values for both milk and type traits for the top bulls when SI greater than zero.

Although selecting for the intercept would provide positive selection for many desirable traits, selection for reduced changes would greatly reduce milk yield. It seems that high-producing cows adapt to a high level of stress by increasing DO; DO stay flat or even improve during the period of low stress. Therefore, selection to reduce the monthly changes is undesirable. However, 
Table 2. Average PTA and type performance index (TPI) from February 2005 US official evaluation for 100 bulls with the longest and 100 bulls with the shortest days open (DO)

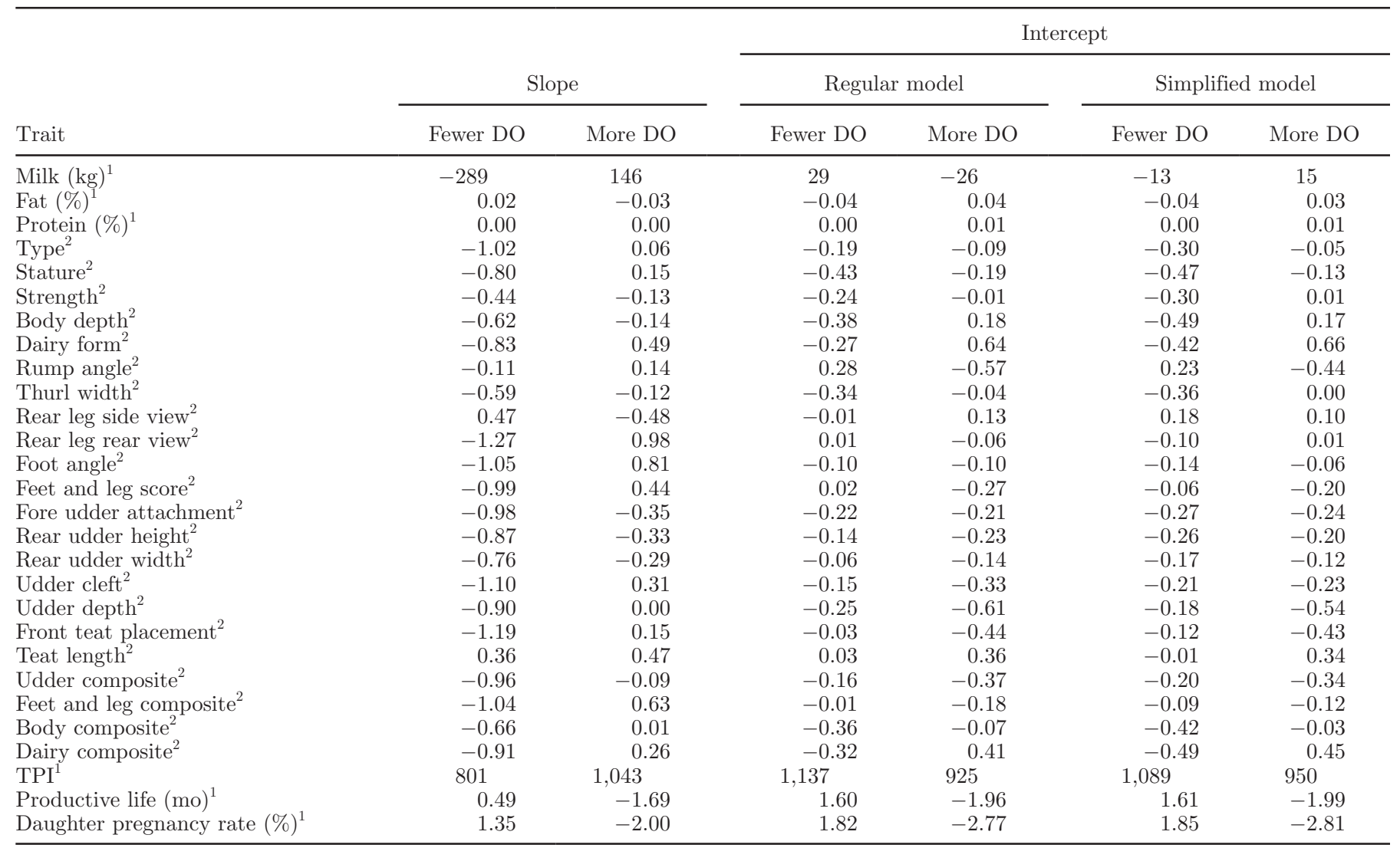

${ }^{1}$ Source: Animal Improvement Programs Laboratory, USDA (Beltsville, MD).

${ }^{2}$ Source: Holstein Association, USA Inc. (Brattleboro, VT).

the model that accounts for the changes can improve evaluations for DO compared with the model that ignores the changes.

This study assumed the same genetic control for the changes in all regions and assumed that the changes were mostly due to heat stress. In fact, the reasons for changes can be different; especially for the Northwest. They may include seasonal feed differences, timing of lactations, time on pastures, and so on. Another assumption was that the genetic parameters for all the regions were the same, while the parameters due to the slope were scaled by the index. However, computations with models with different parameters indicated robustness of the model that assumes homogeneous variances for the animal effects. More accurate trends for heat stress might be obtained by analyzing outcomes of successive inseminations. This will be possible when national data sets become more complete and easily available. In addition, such records require extensive editing (Huang et al., 2008).

\section{ACKNOWLEDGMENTS}

Comments of Marek Lukaszewicz (Institute of Genetics and Animal Breeding of the Polish Academy of Sciences, Jastrzebiec, Poland) and Tomasz Strabel (Poznan University of Life Sciences, Poland) as well as the financial support from Holstein Association USA (Brattleboro, VT) and the Koepon Foundation (Amersfoort, the Netherlands) are gratefully acknowledged.

\section{REFERENCES}

Abdallah, J. M., and B. T. McDaniel. 2000. Genetic parameters and trends of milk, fat, days open, and body weight after calving in North Carolina experimental herds. J. Dairy Sci. 83:1364-1370.

Aguilar, I., I. Misztal, and S. Tsuruta. 2008. Genetic parameters for milk, fat and protein in Holsteins using a multiple-parity test day model that accounts for heat stress. J. Dairy Sci. 91(E-Suppl. 1):544. (Abstr.)

Averill, T. A., R. Rekaya, and K. Weigel. 2004. Genetic analysis of male and female fertility using longitudinal binary data. J. Dairy Sci. 87:3947-3952. 
Berger, P. J., R. D. Shanks, A. E. Freeman, and R. C. Laben. 1981. Genetic aspects of milk yield and reproductive performance. J. Dairy Sci. 64:114-122.

Brouk, M. J., J. P. Harner, J. F. Smith, and D. V. Armstrong. 2007. Environmental modifications to address heat stress. J. Dairy Sci. 90(Suppl. 1):624. (Abstr.)

de Vries, A. 2006. Determinants of the cost of days open in dairy cattle. Proceedings of the 11th Symposium of the International Society for Veterinary Epidemiology and Economics, Cairns, Australia: ISVEE 11:1114.

de Vries, A., and C. A. Risco. 2005. Trends and seasonality of reproductive performance in Florida and Georgia dairy herds from 1976 to 2002 . J. Dairy Sci. 88:3155-3165.

Eicker, S. W., Y. T. Grohn, and J. A. Hertl. 1996. The association between cumulative milk yield, days open, and days to first breeding in New York Holstein cows. J. Dairy Sci. 79:235-241.

Faust, M. A., B. T. McDaniel, O. W. Robison, and J. H. Britt. 1988 Environmental and yield effects on reproduction in primiparous Holsteins. J. Dairy Sci. 71:3092-3099.

Flamenbaum, I., and E. Ezra. 2007. The "summer to winter performance ratio" as a tool for evaluating heat stress relief efficiency of dairy herds. J. Dairy Sci. 90(Suppl. 1):605-606. (Abstr.)

García-Ispierto, I., F. López-Gatius, G. Bech-Sabat, P. Santolaria, J. L. Yániz, C. Nogareda, F. De Rensis, and M. López-Béjar. 2007. Climate factors affecting conception rate of high producing dairy cows in northeastern Spain. Theriogenology 67:1379-1385.

García-Ispierto, I., F. López-Gatius, P. Santolaria, J. L. Yániz, C. Nogareda, M. López-Béjar, and F. De Rensis. 2006. Relationship between heat stress during the peri-implantation period and early fetal loss in dairy cattle. Theriogenology 65:799-807.

Gonzalez-Recio, O., Y. M. Chang, D. Gianola, and K. A. Weigel. 2005. Number of inseminations to conception in Holstein cows using censored records and time-dependent covariates. J. Dairy Sci. 88:3655-3662.

Her, E., D. Wolfenson, I. Flamenbaum, Y. Folman, M. Kaim, and A. Berman. 1988. Thermal, productive, and reproductive responses of high yielding cows exposed to short-term cooling in summer. J. Dairy Sci. 71:1085-1092.

Huang, C., S. Tsuruta, J. K. Bertrand, I. Misztal, T. J. Lawlor, and J. S. Clay. 2008. Environmental effects on conception rates of Holsteins in New York and Georgia. J. Dairy Sci. 91:818-825.

Oseni, S., I. Misztal, S. Tsuruta, and R. Rekaya. 2003. Seasonality of days open in US Holsteins. J. Dairy Sci. 86:3718-3725.

Oseni, S., I. Misztal, S. Tsuruta, and R. Rekaya. 2004a. Genetic components of days open under heat stress. J. Dairy Sci. 87:30223028 .
Oseni, S., S. Tsuruta, I. Misztal, and R. Rekaya. 2004b. Genetic parameters for days open and pregnancy rates in US Holsteins using different editing criteria. J. Dairy Sci. 87:4327-4333.

Pryce, J. E., M. D. Royal, P. C. Garnsworthy, and I. L. Mao. 2004. Fertility in the high-producing dairy cow. Livest. Prod. Sci. $86: 125-135$.

Rajala-Schultz, P. J., and G. S. Frazer. 2003. Reproductive performance in Ohio dairy herds in the 1990s. Anim. Reprod. Sci. 76:127142.

Ravagnolo, O., and I. Misztal. 2002. Effect of heat stress on nonreturn rate in Holstein cows: Genetic analyses. J. Dairy Sci. 85:30923100 .

Ray, D. E., A. H. Jassim, D. V. Armstrong, F. Wiersma, and J. D Schuh. 1992. Influence of season and microclimate on fertility of dairy cows in a hot-arid environment. Int. J. Biometeorol $36: 141-145$.

Rensis, F. D., and R. J. Scaramuzzi. 2003. Heat stress and seasonal effects on reproduction in the dairy cow-A review. Theriogenology 60:1139-1151.

Silva, H. W. C. J. Wilcox, W. W. Thatcher, R. B. Becker, and D. Morse. 1992. Factors affecting days open, gestation length, and calving interval in Florida dairy cattle. J. Dairy Sci. 75:288-293.

Tsuruta, S., I. Misztal, C. Huang, and T. J. Lawlor. 2008. Genetic correlations between conception rates and test-day milk yields using a threshold-linear random-regression model. J. Dairy Sci. 91(E-Suppl. 1):107-108. (Abstr.)

VanRaden, P. M., A. Sanders, M. Tooker, R. Miller, and D. Norman. 2002. Daughter pregnancy rate evaluation of cow fertility. AIPL Presentation. http://aipl.arsusda.gov/reference/fertility/DPR_ rpt.htm. Accessed Sep. 2, 2008.

VanRaden, P. M., A. H. Sanders, M. E. Tooker, R. H. Miller, H. D. Norman, M. T. Kuhn, and G. R. Wiggans. 2004. Development of a national genetic evaluation for cow fertility. J. Dairy Sci 87:2285-2292.

VanRaden, P. M., M. E. Tooker, A. H. Sanders, and G. R. Wiggans. 2003. Quality of data included in genetic evaluations for daughter pregnancy rate. J. Dairy Sci. 86(Suppl. 1):132. (Abstr.)

Washburn, S. P., W. J. Silvia, C. H. Brown, B. T. McDaniel, and A. J. McAllister. 2002. Trends in reproductive performance in southeastern Holstein and jersey dhi herds. J. Dairy Sci. 85:244251.

West, J. W. 2003. Effects of heat-stress on production in dairy cattle. J. Dairy Sci. 86:2131-2144. 